\section{The Way}

\section{See It}

\title{
Point/counterpoint: The value of place
}

\author{
By Frank R. Allen and Sarah Barbara Watstein
}

\section{Two opposing views on what libraries should look and feel like}

\section{Point}

\section{By Frank R. Allen}

I recently had occasion to visit one of the new style of super bookstores in our city. As I entered I was immediately struck by the retailer's deliberate effort to recreate the atmosphere of a private library. Oak finishes adorned the store. Quict reading areas complete with overstuffed seating, coffee tables, and throw rugs were strategically located throughout. Eighteenth-century classical music wafted through the air. The atmosphere was delightful-warm, comforting, and inviting. Later, as I reentered our campus library and rounded the corner into the main reference area, my eyes were immediately greeted with banks of electronic terminals, personal computers, CD-ROM players, and print- ers. I glanced over to my left at the instruction lab, complete with more PCs and computerlinked overhead projectors. Our library is proud to offer this array of technology for our users, but for the most part the first impression one has coming off the street is of a computer lab. What is going on here?

\section{People value place and proximity}

When contemplating this sharp comparison, I am reminded of Saskia Sassen's address at the 7 th National ACRL Conference last April. Sassen spoke about themes from her book, The Global City (P'rinceton Univ. Pr., 1991), in which she points out the increasing tendency for companies in certain industries to agglomerate. In this age of high-speed worldwide communica tion links, she says, it would be entirely possible for firms in the financial services sector to locate their businesses spatially separated from each other. Why then is just the opposite happening? The downtown districts of New York

I understand my colleague's points, however, I do not share his level of concern. Nor do I feel a need to "rally round the flagpole" and "make sure" our libraries are the information epicenters on our campuses. Will every academic campus continue to need an information epicenter in the 21 st century? I am not so sure. Should libraries strive to serve that function? I am not so sure that fulfilling that function is a realistic goal for any single organization.

\section{Place is about connection}

So, "what is going on here?" What is going on here is that information technology is enabling our institutions and our organizations to transcend traditional boundaries. The value of place

Frank R. Allen is bead of Administrative Services for University Library Services at Virginia Commonwealth University (VCU), e-mail: frallen@gems.vcu.edu; Sarab Barbara Watstein is interim direclor of University Computing Services-Academic Campus at VCU, e-mail: suatstei@felix.vcu.edu 


\section{(Allen cont.)}

City, Tokyo, and London have emerged as super-concentrated centers of world financial trade in the last two decades. The paradox is heightened by the fact that the business of finance-that is trading, lending, unclerwriting, insuring, and issuing-is the most liquid, transportable process imaginable. Furthermore, this pattern of agglomeration of financial power is strikingly similar between the three cities, and is being replicated on a smaller scale in regional economic centers across the globe. The phenomenon is not just a quirk of one culture.

Why are these districts prospering and in such similarity to each other? Sassen cannot explain all of it, but at a minimum, she says, we as humans attach a high value to physical place and physical proximity. On a deeper level, she argues, the complexity of financial services requires simultaneous participation of specialized firms that are so interwoven that it is economically advantageous for them to be located physically near each other.

Any thoughtful librarian hearing her address could not have failed to see the analogy: libraries exist and can continue to prosper because people value place and proximity, and because there is an economy and efficiency in agglomerating related functions and services in close physical proximity to one another. The modern, full-service, academic library is actually an agglomeration of related functions. As with the financial services industry, we information professionals don't all do the same thing, but rather a series of related interdependent functions.

\section{The "place-rooted infrastructure"}

What can we learn from these observations? First, let's take a cue from the bookstore marketers and strive to make our libraries places that are physically inviting and warm. While we are upgrading for tomorrow let's also keep investing in creature comforts such as comfortable seating, proper lighting, and aesthetically pleasing color arrangements. Let's not create such sterile high-technology environments that we unknowingly discourage our patrons from lingering or personally collaborating with one another.

Second, let's continue to promote the library as the heart of our campus. Let's provide what Sassen calls the "place-rooted infrastructure"' for our campuses - that physical locale where (Allen cont. on page 383)

\section{(Watstein cont.)}

has not diminished. Nor has the fact that people value place and proximity changed. Information technology has simply changed our conceptualization of place and our understanding of proximity.

Reality isn't what it used to be and virtuality isn't here yet. But, plain and simple, place is not place is not place. Today, place is about connection. It is about access to all types of information. Faster processing. Faster distribution. Today, place is defined both from, and in terms of, our desktops and workstations. Information technology enables us to create place in several different ways. We have the ability to access information whenever we choose. We have the ability to record, send, and receive information from virtually any location: a library, a classroom, a residence hall room, an office, even our homes. We have the ability to retrieve everything and share it with others, or simply print it out ourselves, all from the most remote locations. Place is wherever we are at any given moment, totally unrestricted by walls, service desk hours, and the prerequisite line at the copiers. Place is at our fingertips.
Similarly, our understanding of proximity has evolved. Physical proximity may no longer be as important a definer of proximity as intellectual proximity. Today, proximity is about online collaboration. It is about networked communication. The ability to overcome distance and to create a community in every important sense - this is what proximity is about today, totally unrestricted by the idiosyncrasies of physical locale.

I share my colleague's observation that $\mathrm{li}$ braries exist because people value place and proximity. However, because information technology has enabled people to reframe their understanding of both place and proximity, libraries that expect to continue to exist and prosper as we move towards the millennium would do well to revisit that expectation. Take another look at the computer labs and computer centers, at the desktops and workstations, at your campus. These are places in their own right, places which foster creativity and collaboration, places that beckon our users with a range of services and resources beyond our wildest dreams. Reason to be troubled, concerned, and cautious? I think not. Just the opposite! 


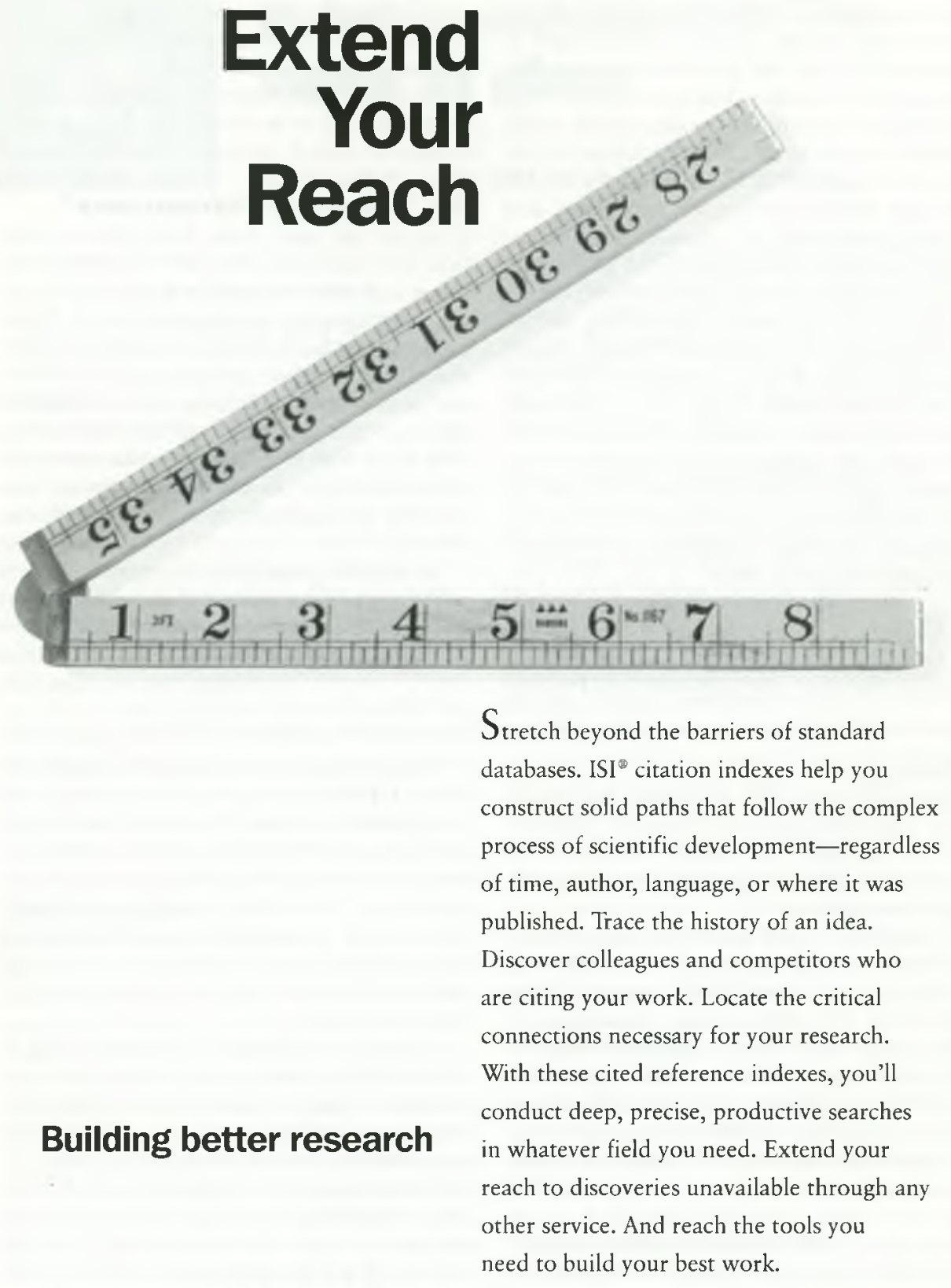

Citation Indexes

exclusively from

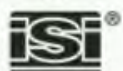

For more information, call 1-800-336-4474 or 215-386-0100 (U.S., Canada, Mexico) +44-1895-270016 (Outside U.S.) http://www.isinet.com

두 1996 Institute for Scientific Information 
books are seven dating from 1790 to 1833 , including the woodboard-bound $1790 \mathrm{~A}$ Grammatical Institute of the English Language and an 1827 Hale's History of the United States. Other valuable additions include a turn-of-the-century edition of The Baby's Opera by noted English illustrator Walter Crane, a first edition of The Wizard of $\mathrm{Oz}$, and an 1866 edition of Evangeline.

\section{A large collection of more than}

3,000 books, magazines, and other materials relating to the downtown New York writing scene from 1975 to the present has been acquired by the Fales Library of New York University. To be known as the

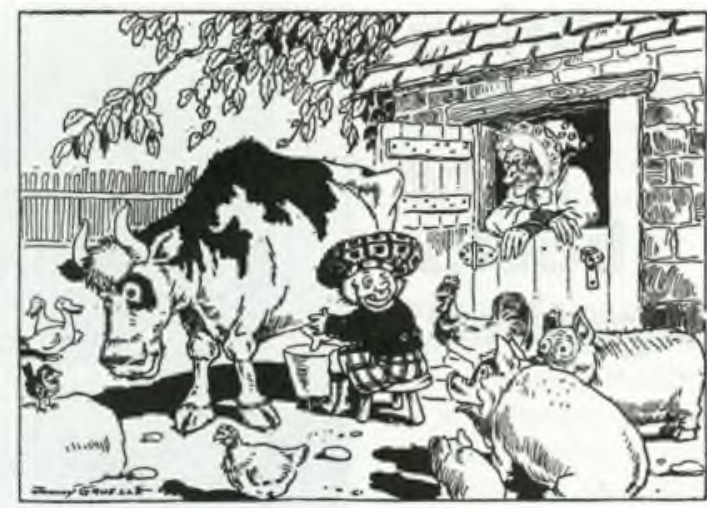

The Wee, Wee Mannie and the Big, Big Coo from $M y$ Bookbouse-In the Nursery' (1925) at U of I-Urbana.
"Downtown Writers Collection." the materials were collected by Ron Kolm, a poet, editor, and member of the downtown scene. The collection includes signed first editions by such authors as Kathy Acker, Lynne Tillman, Gary Indiana, Walter Abish, Spalding Graly, Patrick McGrath, and Harry Mathews. Also featured are complete runs of important literary magazines of the period, 'zines, posters, flyers, catalogs of exhibitions, and announcements for readings, all of which give a sense of the arts scene during the height of the Soho and East Village writing explosion.

\section{(Allen cont. from page 373)}

teaching, collaborating, and information transfer all come together. For some universities this will continue to occur naturally. At other campuses we may need to work to maintain this presence. For one thing, we can remind our campus administrators of the wide array of services provided by libraries, which includes providing increasingly sophisticated user instruction (it is drastically easier to show patrons how to navigate electronic resources in person versus over the phone or through an e-mail response), providing $\mathrm{A} / \mathrm{V}$ labs for asynchronous lecture delivery, and providing study environments for students and discussion groups, just to name a few.

\section{The hub of the campus}

Let's also look for additional ways to bring users into the library to expose them to our services. Our library houses the offices for the new campus universal I.D. card, named One-Card. Our library faculty had initially engaged in lively
The papers of Canadian children's writer Carol Matas have been acquired by the University of Manitoba Libraries. Matas's book Lisa received both the Geoffrey Bilson Award for Historical Fiction for Young Readers and a Notable Book Award from the New York Times Book Review. The collection includes handwritten and typed drafts and revisions of her published and unpublished novels, stories, and plays; correspondence to publishers, agents, and readers; and research notes and signed copies of various editions of her 14 published novels.

discussion about the pros and cons of placing this center in the building. In the end we came to the realization that putting the office in the library would reinforce the concept of the library being the hub of campus. As it turns out, we are able to refer students downstairs who have questions about the cards. We now have an additional opportunity to promote library orientation sessions to students by placing strategically located signage in their paths as they come into the building for their I.D. cards.

The virtual library will certainly arrive and not a moment too soon for libraries that are bursting at the seams with print material collections. But every academic campus will continue to need an information epicenter. Let's make sure it's the library.

\section{Nore}

1. Sassen is quoted in Ellen K. Coughlin, "Global Perspectives on the Economy," Chronicle of Higher Education 42 (January 12, 1996): A8. 